\title{
ACESSO A RECURSOS GENÉTICOS HUMANOS: UMA ABORDAGEM CONSENSUAL
}

\author{
Roberto Chacon de Albuquerque \\ Doutorando pelo Departamento de Direito Civil da \\ Faculdade de Direito da Universidade de São Paulo
}

\begin{abstract}
Resumo:
O artigo analisa as questões éticas e jurídicas relacionadas à coleta de recursos genéticos humanos. Enfatiza-se a importância de obter-se consentimento informado dos indivíduos ou grupos que forem objeto de pesquisas biomédicas.
\end{abstract}

\begin{abstract}
:
The article analyzes the ethical and legal questions related to the collection of human genetic features. It emphasize the importance to get informed assent of the individuals or groups that will be object of biomedical research.
\end{abstract}

Unitermos: genética; privacidade; patente; consentimento.

Introdução:

Muitas pessoas ou grupos acreditam que os genes revelam sua essência mais íntima, atribuindo-lhes um enorme valor espiritual e comercial. A manutenção da propriedade sobre o patrimônio genético, a atualidade profunda de nossa vida, pode constituir um fator fundamental para que um individuo, uma família ou um grupo étnico mantenha controle sobre seus recursos intelectuais, científicos e culturais.

Uma abordagem consensual pode evitar a discussão espinhosa sobre a existência ou-não de direitos de propriedade sobre o ADN'

1. O ADN - o ácido desoxirribonucléico -, o "portador da mensagem genética", pode ser imaginado "como uma longa fita cm quc cstão 'cscritas', cm letras quimicas, as nossas caractcrísticas (por cxemplo, cabclo claro ou escuro, encaracolado ou liso, tendência à calvícic, altura maior ou menor, até mais ou menos tendência à introspcç̧ão, ctc.)" (Cf. Espinosa, Jaimc. São Paulo: Quadrantc, 1998, p. 71). 
humano ${ }^{2}{ }^{3}$ Por outro lado, uma abordagem consensual também apresenta seus inconvenientes, caso um pesquisador transfira amostras de ADN humano para uma instituição que não tenha assinado nenhuma espécie de acordo de transferência. Mesmo neste caso, uma empresa farmacêutica, tendo em vista os riscos de publicidade adversa, antes de gastar milhões de reais no desenvolvimento de um fármaco, preferirá provavelmente obter o consentimento de quem forneceu o $\mathrm{ADN} .{ }^{4} \mathrm{O}$ consentimento informado deveria assumir a natureza de um contrato que vinculasse as partes. ${ }^{5}$ Qualquer pessoa interessada em ter acesso a recursos genéticos de origem humana, ${ }^{6}$ estejam eles registrados numa base de dados ou armazenados num depósito, deveria subscrever um acordo de acesso ou um acordo de transferência.?

Conforme o precedente Moore v. Regents of University of California ${ }^{8}$ indivíduos que forem objeto de uma pesquisa genética não teriam necessariamente direito a obter qualquer espécie de compensação financeira. ${ }^{?}$

\section{Privacidade}

A pesquisa tendo como objeto uma família ou um grupo de famílias com uma alta incidência de uma doença genética pode revelar que tal família ou grupo

2. A Lei n. 10.205/01 proibe a venda de sangue c scus derivados no País. A nova lci cstabclece uma política formal para o setor, define metas de auto-suficiência na produção c constitui o Sistcma Nacional de Sangue (Sinasan), órgão que controla a cxccução das políticas voltadas para a produção $c$ distribuição do produto. Como se proíbc a venda de sanguc $\mathrm{e}$ seus derivados, talvez se pudesse argumentar que se proíbc também a venda de ADN, que constituiria um bem fora do comćrcio, insusceptível de apropriação privada.

3. Greely, Henry T. The Control of Genetic Rescarch: Involving the "Groups Between" Houston Law Review, 33(5):1419, 1997.

4. Idem, ibidem, p. 1419.

5. Idem, Legal, Ethical, and Social Issucs in Human Genomc Rescarch. Annu. Rev. Anthropol., (27):494, 1998.

6. Com a expressão "recursos genéticos humanos", abrangc-sc tanto gencs quanto protcínas c outras moléculas humanas.

7. Greely, Henry T. The Control of Genetic Rescarch: Involving the "Groups Between". Houston Law Review, 33(5):1419, 1997.

8. Moore v. Regents of Univ. of Cal., 793 P.2d 479 (Cal. 1990).

9. Greely, Henry T. The Control of Genetic Rescarch: Involving the "Groups Bctween" Houston Law Review, 33(5): 1420, 1997: "On the other hand, individual research subjects may not have the legal ability under Moore v. Regents of University of California, or the practical ability under the conditions of research, to garner any financial return from their role in the research." 
de famílias têm mais probabilidade de carregar um alelo defeituoso de um gene. ${ }^{10}$ Esta informação terá conseqüências para todos os membros da família. Cada membro saberá que ele, seus pais, seus filhos, bem como todos seus parentes, terão uma grande probabilidade de desenvolver uma doença genética específica. Uma família conhecida por ser portadora de uma doença genética pode ter dificuldades em associar-se a planos de saúde. A mesma dinâmica aplica-se a grupos étnicos, com implicações extremamente significativas."

A Dra. Nancy Wexler e outros cientistas, a partir de pesquisas com uma família na Venezuela, identificaram o gene responsável pela doença de Huntington ${ }^{12} 13$ O estudo Tuskegee ${ }^{14}$ sobre sífilis, estimulou nos EUA a adoção de um extenso mecanismo de regulamentação da pesquisa biomédica. ${ }^{15}$

Da mesma maneira que os indivíduos, os grupos objeto de pesquisas genéticas também podem desejar preservar sua privacidade. Todavia, sobretudo no caso de populações reduzidas, isto não constituirá uma tarefa fácil. ${ }^{16}$ Tal discussão também deveria fazer

10. Jdem, ibidem, p. 1411.

II. Id., ib., p. 1411.

12. Qucm tivesse doença hereditária, na Alcmanha nazista, podia scr cstcrilizado cirurgicamentc quando, de acordo com parecer médico, houvesse grande probabilidade de que seus descendentes sofreriam de scveras docnças congênitas de naturcza física ou psíquica. Docnte hercditário, no scntido da Lci para Prcvenção do Nascimento de Descendentes com Docnças Hercditárias (Gesetz zur Verhïtung erbkranken Nachwuchses vom 14 Juli 1933. Reichsgesetzblatt, 25 Juli 1933, n. 86, Scção I, pp. 529-531), cra qucm sofresse de uma dessas docnças: "1. Fracos de cspírito (sic); 2. Esquizofrenia; 3. Maniaco-depressivos; 4. Epilcpsia hereditária; 5. Corćia de Huntington ; 6. Ccgucira hereditária; 7. Surdez hereditária; 8. Sćria deficiência física hcreditária"

13. Grecly, Henry T. The Control of Genctic Rescarch: Involving the "Groups Betwecn". Houston Law Review, 33(5): 1428, 1997: "For example, Dr. Nancy Wexler and others used an extended family in Venezuela to locate the gene for Huntington's disease."

14. "Nos anos 30, ainda não se sabia ao ccrto se a sifilis tinha os mesmos cfeitos $\mathrm{cm}$ brancos c ncgros. Para dilucidar o assunto, o Serviço de Saúde Pública dos EUA criou um centro de assistência médica cm Macon, no Alabama, oficialmente dedicado ao tratamento gratuito da população carente. Dentre os trabalhadores da árca rural que assinaram um documento em que concordavam $\mathrm{cm}$ participar de um programa gratuito de ajuda mćdica proposto pclo governo, sclecionaram-se 399 ncgros nos quais sc diagnosticara sifilis, cmbora nenhum deles tivesse consciência de sofrer dessa doença. Enquanto se simulava um tratamento - na realidade, recebiam apenas placcbos ('remédios' com a aparência normal de pílulas, comprimidos $\mathrm{cm}$ gotas, mas scm princípio ativo, isto ć, scm qualquer cfeito curativo) -, cstudavam-sc os progressos da sifilis no seu organismo. E isso perdurou mesmo depois de descobcrta a penicilina, que permitc curar cssa doença." (Cf. Espinosa, Jaime. São Paulo: Quadrante, 1998, p. 64).

15. Greely, Henry T. The Control of Genetic Rescarch: Involving the "Groups Betwecn". Houston Law Review, 33(5):1400, 1997.

16. Proposed Model Ethical Protocol for Collecting DNA Samples. Houston Law Review, 33(5):I463, 1997. 
parte do processo de obtenção do consentimento informado. Caso o grupo desejar manter, sob qualquer circunstância, sua privacidade, o pesquisador deveria, ao verificar a impossibilidade de atender a esta exigência, desistir da coleta de ADN desse grupo. ${ }^{17}$

Também se deveria discutir em que medida tanto os indivíduos quanto o grupo desejam ser informados das doenças, hereditárias e não-hereditárias, que forem detectadas a partir do exame das amostras de ADN. Tal discussão também deveria fazer parte do processo de obtenção do consentimento informado. Em princípio, apenas os indivíduos deveriam ser informados das doenças, hereditárias e não-hereditárias, que forem detectadas a partir do exame das amostras de seu ADN. A divulgação de tais resultados, especialmente no caso de doenças infecciosas de alto risco, pode levar, em situações extremas, ao assassinato. Tampouco se pode descartar que os próprios indivíduos acometidos de doenças hereditárias jamais desejem ficar a par desta situação. $^{18}$

Nem sempre será possível eliminar toda espécie de informação que identifique o doador ${ }^{19}$ da amostra de ADN, o que tampouco seria desejável em todas as circunstâncias. Muitas vezes, para que se analise uma amostra de ADN, será preciso que se conheçam várias características individuais do doador, como, por exemplo, seus vínculos de parentesco. ${ }^{20}$ Todo pesquisador deveria comprometer-se a manter em segredo tais informações, só as revelando a terceiros pesquisadores que também se comprometam a mantê-las em segredo. ${ }^{21}$

A utilização de ADN pela Medicina Legal, com a criação de bancos de dados com o ADN de supostos criminosos, também pode colocar em risco a proteção à privacidade. $\mathrm{O}$ primeiro caso de teste de $\mathrm{ADN}$ num contexto penal ocorreu numa área rural inglesa, após um estupro seguido de assassinato. Solicitou-se a jovens de aldeias vizinhas que fornecessem amostras de seu $\mathrm{ADN}$, que seriam confrontadas com o ADN do criminoso, encontrado no corpo da vítima. Um homem pagou a um conhecido

17. Ibidem, p. 1.464 .

18. Ib., p. 1.459: "Others may find such knowledge an unbearable burden."

19. Doadores, na maioria das vezes, serão identificados a partir de seus nomcs.

20. Proposed Model Ethical Protocol for Collecting DNA Samples. Houston Law Review, 33(5): 1.462, 1997.

21. Ibidem, pp. 1.462-1.463. 
para que este fornecesse uma amostra de $\mathrm{ADN}$ em seu nome. $\mathrm{O}$ conhecido relatou este pedido à polícia, o que levou à prisão e condenação do suspeito. ${ }^{22}$

Se um indivíduo ou um grupo desejar, deveria ser-lhes facultada a possibilidade de serem destruídas as amostras de ADN que foram coletadas com sua participação, bem como os respectivos dados. Caso os dados houverem sido publicados, eles não poderão ser destruídos. ${ }^{23}$

\section{Eugenia}

Em quase todos os seres humanos, a imensa maioria dos genes são praticamente idênticos. ${ }^{24}$ Existe uma enorme diversidade genética dentro de todos os grupos étnicos, e uma pequena diversidade genética entre eles. ${ }^{25}$ Geneticamente, os seres humanos constituem uma espécie bastante homogênea. ${ }^{26}$

Muitos países, como a Alemanha, os EUA, a Suécia e o Reino Unido esterilizaram coercitivamente, sobretudo na primeira metade do século $\mathrm{XX}$, indivíduos que apresentavam supostamente predisposição genética para a criminalidade ou a debilidade mental. A Corte Suprema dos EUA pronunciou-se ${ }^{27}$, uma vez, em finais da década de 20, no sentido de que "três gerações de imbecis é o suficiente" ${ }^{28}$ A experiência alemã, durante o Terceiro Reich, desacreditou a eugenia, reforçando a compreensão crescente da importância do meio, não apenas das características hereditárias, sobre o desenvolvimento físico e mental do individuo. ${ }^{29}$

22. Grecly, Henry T. Legal, Ethical, and Social Issues in Human Genome Rescarch. Annu. Rev. Anthropol., (27):476-477, 1998.

23. Brasil, Consclho Nacional de Saúde. Normas de Pesquisa cm Saúde (Resolução n. 01/88): "Art. $6^{\circ}$ Nas pesquisas com seres humanos proteger-sc-á a privacidade do indivíduo objeto da pesquisa, identificando-o somente quando os resultados o requeiram c cstc o autorize." (Cf. SANTOS, Maria Celeste Cordciro Leite. O cquilíbrio de um pêndulo: bioćtica c a lci: implicações médico-lcgais. São Paulo: Íconc Editora, 1998, pp. 245-270).

24. Grecly, Henry T. The Human Genome Diversity Project: Ethical, Legal, and Social Issues. In: Genetics; Issues of Social Justice. Clcveland, The Pilgrim Library of Ethics, p. 72.

25. Idem, The Control of Genctic Rescarch: Involving the "Groups Betwecn". Houston Law Review, 33(5):1.418.

26. Id., ibidem, p. 1.418: "Genetically, humans are a fairly homogenous species."

27. Buck v. Bcll, 274 US 200 (1927).

28. Grecly, Henry T. Legal, Ethical, and Social Issues in Human Genome Rescarch. Annu. Rev. Anthropol, (27):483, 1998: "The US Supreme Court, in an opinion by Justice Holmes, upheld one such statute (Buck v. Bell 1927) with the famous words 'three generations of imbeciles are enough, ' [...]"

29. Idem, ibidem, p. 484. 
Jamais se comprovou que um grupo étnico, em virtude de suas características genéticas, tenha qualquer espécie de vantagem ou desvantagem em relação a outros grupos étnicos. ${ }^{30}$ Todavia, de acordo com as circunstâncias políticas, um grupo étnico pode ser considerado racialmente inferior ou superior ${ }^{31}$ em virtude se suas características genéticas. ${ }^{32}$ A falta de argumentos científicos em favor da eugenia não quer dizer que outros argumentos políticos não sejam levantados em seu favor, em detrimento de minorias étnicas. ${ }^{33}$

Algumas variedades de alelos são mais comuns em alguns grupos étnicos do que em outros. ${ }^{34}$ Uma boa parte das pesquisas genéticas sobre o diabetes foi feita com a tribo Pima, do Arizona, ${ }^{35}$ que sofre bastante desta doença ${ }^{36}$ Uma maior incidência de características genéticas consideradas negativas num grupo étnico pode levar seguradoras de saúde a recusar sistematicamente seus membros.

A imensa maioria da variedade genética na Humanidade, cerca de $85 \%$, concentra-se dentro de qualquer grupo étnico. Sendo assim, dois finlandeses têm maior probabilidade de serem mais diferentes geneticamente do que um finlandês "mediano" de um coreano "mediano" ${ }^{37} \mathrm{O}$ conceito de "raça pura" é um conceito exclusivamente cultural, e não-científico. ${ }^{38}$

Apenas raramente, no caso de sérias doenças hereditárias, a vida de um

30. -. Proposed Model Ethical Protocol for Collccting DNA Samplcs. Houston Law Review, 33(5):1465, 1997.

31. Grecly, Henry T. Legal, Ethical, and Social Issucs in Human Genome Rescarch. Anmu. Rev. Anthropol., (27):478, 1998.

32. -- Proposed Model Ethical Protocol for Collecting DNA Samples. Houston Law Review, 33(5):1.465, 1997: "In all but the most literally superficial ways, humans are just not very different genetically."

33. Grecly, Henry T. Legal, Ethical, and Social Issucs in Human Genome Rescarch. Annu. Rev. Anthropol., (27):484, 1998.

34. Idem, ibidem, p. 483.

35. Lll, Patents, and Indigenous Pcoples. Cultural Survival Quarterly (Summcr 1996), p. 5.

36. Id., Mapping the Genomc. The Uthe Reader (Mar. 1996), p. 2.

37. Id., Iccland's Plan for Genomics Rescarch: Facts and Implications. Jurimetrics Journal of Law, Science and Technology, 40(2):160, Winter 2000.

38. Idl., The Human Genome Diversity Project: Ethical, Legal, and Social Issues. In: Genetics; Issues of Social Justice. Clcveland, The Pilgrim Library of Ethics, p. 73. 
ser humano é determinada por sua herança genética. Para a imensa maioria, a história de vida de cada um é que influencia preponderantemente o curso de sua existência. ${ }^{39}$ Doenças hereditárias, com freqüência, podem ser o resultado não de um gene específico, mas de uma combinação de genes.

O Código Brasileiro de Ética Médica, art. 122, veda ao médico participar de qualquer tipo de experiência no ser humano com fins eugênicos.

\section{Patenteamento}

O resultado de pesquisas genéticas já possibilitou o desenvolvimento de medicamentos, bem sucedidos sob o ponto de vista comercial, destinados ao tratamento de doenças hereditárias. Como dividir os benefícios comerciais, o lucro, de medicamentos desenvolvidos a partir do resultado de pesquisas efetuadas, tendo por base o estudo das características genéticas de indivíduos, famílias ou grupos étnicos? Nada teria sido descoberto, caso não se tivesse levado em consideração o contexto familiar ou grupal. Desta maneira, dificilmente um indivíduo isolado teria direito, per $\mathrm{se}$, a royalties. Os beneficios comerciais, em tese, deveriam ser compartilhados entre os pesquisadores e a família ou grupo étnico objeto da pesquisa. Todavia, este princípio pode tornar-se inexecutável, caso membros dispersos de uma família ou de um grupo étnico tenham, desde o princípio, participado isoladamente da pesquisa. ${ }^{40}$

Instituições governamentais talvez não constituam o beneficiário ideal da utilização comercial, bem como do patenteamento, de recursos genéticos humanos. ${ }^{41}$ Existem várias associações, muitas vezes sem fins lucrativos, que apóiam tanto a pesquisa quanto o tratamento de várias doenças, como o diabetes, cardiopatias, etc. Tais associações poderiam constituir o beneficiário ideal da utilização comercial, bem como do patenteamento, de recursos genéticos humanos. Assim, não se estimularia a exploração comercial de ADN humano. ${ }^{42}$

Muitos argumentam que nenhum indivíduo deveria beneficiar-se da 1998.

39. Id., Lcgal, Ethical, and Social Issucs in Human Genomc Rescarch. Annu. Rev. Anthropol., (27):496,

40. Id., The Control of Genetic Research: Involving the "Groups Betwecn". Houston Law Review, 33(5): 1.413, 1997.

41. Id., ibidem, p. 1.420 .

42. Id., ib., p. 1.423 . 
utilização comercial, bem como do patenteamento, de recursos genéticos humanos. ${ }^{43}$ O ADN humano deveria constituir um bem fora do comércio. Talvez o direito devesse proibir que se pagasse qualquer indivíduo pela participação em pesquisas genéticas, seja direta ou indiretamente, mediante uma repartição dos benefícios advindos da utilização comercial, bem como do patenteamento, de recursos genéticos humanos, ${ }^{44}$ desde que ninguém pudesse patentear genes, proteínas e outras moléculas humanas, bem como medicamentos derivados de recursos genéticos humanos.

A questão da propriedade de tecidos humanos é uma questão extremamente delicada. No Brasil, nenhum indivíduo pode ser considerado proprietário de seu próprio corpo. Se o fosse, estaria autorizado a vender partes dele, seus órgãos. Também nos EUA, tampouco se admite a venda de órgãos humanos ${ }^{45}$ Por outro lado, o Direito americano admite, com variações de Estado para Estado, a venda de sangue, de óvulos e de esperma. ${ }^{46}$

Quem deveria ser considerado proprietário do material genético humano, ${ }^{47}$ já coletado? O precedente Moore v. Regents of University of California rejeitou a tese de que um paciente era proprietário de um segmento celular derivado de um tecido que the fora removido cirurgicamente, embora se tenha reconhecido o direito de o paciente, John Moore, provar que não dera seu consentimento informado a esta espécie de procedimento, a extração de um segmento celular a partir de um tecido removido cirurgicamente. A Suprema Corte da Califórnia decidiu que John Moore, cujo baço fora retirado cirurgicamente, não era proprietário de um segmento celular proveniente desse seu órgão. ${ }^{48}$ Tal precedente não constitui um leading case, não tendo

43. Idl., ib., p. 1.429.

44. Ill, ib., p. 1.429.

45. Id., Legal, Ethical, and Social Issucs in Human Genome Rescarch. Anmu. Rev. Anthropol, (27):488, 1998. "Thus, in the United States, competent adults are not legally able to exercise one of the prime characteristics of a property right with respect to their organs: They are not allowed to sell them."

46. Ill., ibidem, p. 488.

47. A cxpressão "matcrial genćtico humano", neste texto, ć utilizada com o mesmo significado de "rccurso genćtico humano".

48. Grecly, Henry T. The Ethics of the Human Genome Diversity Project: The North American Regional Committce's Proposed Model Ethical Protocol. In: Human DNA: Law and Policy; International and Comparative Perspectives. The Haguc/London/Boston, Kluwer Law International, p. 248: "In that case, the California Supreme Court held that a patient whose spleen had been surgically removed could not claim a property interest in a cell-line developed from the spleen." 
sido seguido por outros tribunais. ${ }^{3}$ A importância do precedente Moore v. Regents of University of Califórnia concentra-se na discussão levantada por John Moore, a distribuição eqüitativa do lucro proveniente da exploração comercial de recursos genéticos humanos.

Atualmente, a questão mais controversa é o patenteamento de invenções derivadas da análise científica de material genético humano. O patenteamento de genes humanos, de proteínas humanas e de outras moléculas humanas, bem como de medicamentos derivados de genes, proteínas e moléculas provenientes de seres humanos, constitui um assunto sobre o qual ainda não se atingiu um consenso internacional. ${ }^{4}$

O patenteamento de invenções derivadas da análise científica de material humano não-implica a concessão de patentes sobre seres humanos. São invenções derivadas de materiais genéticos humanos, que foram descobertos, purificados e para os quais se encontrou alguma utilização comercial. Ainda não se patenteou um ser humano modificado geneticamente, tampouco uma quimera, um ser parcialmente humano, parcialmente animal.

Stuart A. Newman, biólogo celular no New York Medical College em Valhalla, solicitou a concessão de uma patente sobre um método para criar criaturas que são parcialmente humanas e parcialmente animais, ${ }^{5}$ supostamente para chamar atenção sobre a concessão de patentes sobre formas de vida. ${ }^{6}$ Já se concederam patentes nos EUA sobre animais com componentes humanos, incluindo camundongos com genes cancerígenos humanos ou com células do sistema imunológico humano. ${ }^{7} \mathrm{Não}$ se concedem patentes nos EUA sobre seres humanos, em função da $13^{\text {a }}$ Emenda à Constituição, que proíbe a escravidão. Mas ainda não se decidiu quão humano um animal tem de ser para ser considerado digno de receber tal proteção. ${ }^{8}$

49. Idem, Legal, Ethical, and Social Issucs in Human Genome Rescarch. Annu. Rev. Anthropol., (27):488, 1998.

50. -. Proposed Model Ethical Protocol for Collecting DNA Samples. Hotston Law Review, 33(5): 1466, 1997.

51. Wciss, Rick. Doctor Secks Patent for Process Merging Human and Animal DNA. http://wwwtcch,mit.cdu/V118/N16/cdoc.16w.html (17/02/00).

52. Idem, ibidem.

53. Id., ib.

54. Id., ib. 
O corpo humano e a descoberta de seus elementos não podem ser patenteados, mas um elemento isolado ${ }^{55}$ do corpo humano pode. O titular de uma patente pode controlar toda utilização comercial que se conferir a uma seqüência de $\mathrm{ADN}$ humano. ${ }^{56}$ Não podem ser patenteadas invenções que forem contra os bons costumes e a ordem pública. ${ }^{57}$

Caso se obtenham ganhos a partir da exploração comercial do ADN coletado, os lucros respectivos deveriam ser eqüitativamente distribuídos entre o pesquisador e a população pesquisada. ${ }^{58}$ Doadores individuais de ADN raramente conseguirão comprovar que sua contribuição, per se, desempenhou um papel fundamental, já que a maioria das pesquisas com material genético humano depende da contribuição de vários indivíduos. Qualquer pesquisador que tivesse acesso às amostras de ADN, após elas serem coletadas, também deveria comprometer-se contratualmente a distribuir eqüitativamente os lucros obtidos com a exploração comercial do ADN coletado. Como mencionado anteriormente, a partir de amostras de ADN, podem-se patentear genes, proteínas e outras moléculas humanas, bem como medicamentos derivados de genes. ${ }^{59}$

Duas abordagens poderiam ser adotadas. Primeiro, ninguém deveria patentear genes, proteínas e outras moléculas humanas, bem como medicamentos derivados de genes, sem a autorização expressa da população objeto da coleta de ADN. Segundo, quem quer que obtivesse lucro com a exploração comercial de ADN coletado, pagaria royalties a um órgão designado, que seriam utilizados em benefício da população objeto da coleta de $\mathrm{ADN}$. À população objeto da coleta de ADN deveria ser dada a opção de escolher entre estas duas alternativas. ${ }^{60}$ Caso não se distribuam equiitativamente os lucros obtidos com a exploração comercial do ADN coletado, esta modalidade de pesquisa genética pode terminar sendo desacreditada. ${ }^{61}$

55. Por cxcmplo, uma scqüiência de um genc.

56. Grecly, Henry T. Legal, Ethical, and Social Issues in Human Genome Rescarch. Anmu. Rev. Anthropol., (27):489, 1998.

57. Por excmplo, clones de scres humanos, cmbriões humanos e modificações genćticas de animais que impliquem sofrimento para os mesmos scm um ganho substancial para o ser humano ou animal.

58. Proposed Model Ethical Protocol for Collecting DNA Samples. Houston Law Review, 33(5):1.466, 1997.

59. Ibidem, p. 1.466.

60. /b., p. 1.467.

61. Ib., p. 1.467. 
A concessão de patentes sobre genes pode estimular o surgimento de oligopólios no seio da indústria biotecnológica. ${ }^{62}$ Custa cerca de US\$ 100 mil a US\$ 500 mil manter uma patente nos EUA e em outros países industrializados, durante seu período de validade, de 10 a 20 anos. Defender uma patente de infratores custa ainda mais. Nos EUA, estima-se que custe em média US\$1.600 mil, por patente contestada. Litígios envolvendo patentes sobre genes, devido à sua complexidade biológica e jurídica, devem custar ainda mais. ${ }^{63}$

\begin{tabular}{|c|c|c|}
\hline \multicolumn{2}{|c|}{ EMPRESAS QUE MAIS OBTIVERAM PATENTES SOBRE GENES HUMANOS } \\
\hline EMPRESA & $\begin{array}{c}\text { QUANTIDADE DE } \\
\text { PEDIDOS DE PATENTES }\end{array}$ & $\begin{array}{c}\text { QUANTIDADE DE } \\
\text { PATENTES NOS EUA }\end{array}$ \\
\hline Incyte Genomics & $7000+$ & 560 \\
\hline Human Genome Sciences & $7500+$ & 162 \\
\hline Celera Genomics & Desconhecida & Espera obter de 100 a 300 \\
\hline Hyseq & 5500 & 0 \\
\hline Millenium & $500+$ & $50+$ \\
\hline
\end{tabular}

Fontc: Scicncc, (291):1194, $16 \mathrm{Fcb} .2001$.

Tanto os EUA quanto a União Européia e o Japão já patentearam invenções que incluíam informações sobre material genético humano. Tais patentes encaixam-se usualmente na categoria de patentes químicas de origem orgânica. Embora o componente químico possa ser encontrado na natureza, um processo destinado à produção de uma substância com maior grau de pureza ou maior eficácia do que a

62. Grecly, Henry T. Legal, Ethical, and Social Issues in Human Genome Rescarch. Annu. Rev. Anthropol., (27):490, 1998.

63. - Will a Smaller Genome Complicatc the Patent Chasc? Science, (291):1194, 16 Fcb. 2001: "Patent experts estimate it costs $\$ 100,00010 \$ 500,000$ simply to maintain a single patent over its 10- to 20-year life-span in the United States and other industrialized nations. And actively preventing other companies from infringing is far more costly: in the United States, for instance, legal defenses typically cost $\$ 1.6$ million per contested patent, according to statistics compiled by the U.S. Patent and Trademark Office (PTO). Gene patent fights, PTO officials say, are likely to be even more expensive because of their biological and legal complexity." 
encontrada na natureza pode ser patenteado. O ADN humano tem sido patenteado como qualquer outro componente químico de origem orgânica. ${ }^{64}$

O Comitê Internacional de Bioética, com sua Declaração Universal de Direitos no Genoma Humano, rejeita a idéia de que alguns, em detrimento de outros, deveriam extrair lucros do genoma humano. ${ }^{65}$ Os argumentos contra o patenteamento de genes, sobretudo os de origem humana, incluem afirmações com substrato religioso, como o de que não se pode patentear a vida. ${ }^{66}$ Também se sustenta que os genes são descobertos, e não-inventados. ${ }^{67}$

O Governo da Islândia autorizou que uma empresa privada, a deCODE, desenvolvesse uma base de dados com informações genéticas obtidas da população islandesa. Tais informações genéticas poderão ser exploradas comercialmente. As informações genéticas da população islandesa foram transformadas numa commodity. ${ }^{68}$ O governo será compensado por tal exploração, mas não sob a modalidade de royalties. ${ }^{69}$

\section{Consentimento informado}

Depois da Segunda Guerra Mundial, com o Tribunal de Nurembergue, as potências aliadas promoveram o julgamento de vários médicos e cientistas nazistas, envolvidos em atrocidades na prática de experiências médicas com seres humanos. ${ }^{70} \mathrm{O}$ Código de Nurembergue para pesquisa médica nasceu dentro deste contexto. O Código

64. Grecly, Henry T. Legal, Ethical, and Social Issucs in Human Genome Rescarch. Anmu. Rev. Anthropol., (27):489, 1998: "For the patent offices, human DNA has largely been just another complex organic chemical."

65. Idem, ibidem, p. 490.

66. Ver Declaration of Indigenous Pcoples of the Western Hemisphere Regarding the Human Genome Diversity Project http://www,indians.org/welker/genomc.htm (17/02/00)): "We oppose the patenting of all natural genetic materials."

67. Grecly, Henry T. The Ethics of the Human Genome Diversity Project: The North Amcrican Regional Committce's Proposed Model Ethical Protocol. In: Human DNA: Law and Policy; International and Comparative Perspectives. The Haguc/London/Boston, Kluwer Law International, p. 248.

68. Iclem, Iccland's Plan for Gcnomics Rescarch: Facts and Implications. Jurimetrics Journal of Law, Science and Technology, 40(2): 177, Winter 2000.

69. Id., ibidem, pp. 187-188: "Nothing in the Act provides the government of Iceland with any ownership in deCODE or any royalties from the licensee's use of the Health Sector Database."

70. Id., The Control of Genctic Rescarch: Involving the "Groups Between" Houston Law Review, 33(5):1.407, 1997. 
de Nurembergue ${ }^{71}$ acentua a importância fundamental do consentimento informado, ${ }^{72}$ o contrário do que ocorreu durante as experiências médicas nazistas. ${ }^{73}$ As vítimas de tais experiências não poderiam jamais ser consideradas voluntárias, muito menos voluntárias informadas. ${ }^{74} \mathrm{~A}$ Declaração de Helsinque ${ }^{75}$ também exige o consentimento informado, à semelhança do Código Brasileiro de Ética Médica ${ }^{76} 77$

71. Código de Nuremberguc (Tribunal Internacional de Nuremberguc - 1947): “1. O consentimento voluntátio do ser humano ć absolutamente essencial. Isso significa que as pessoas que serão submetidas ao experimento devem ser legalmente capazes de dar consentimento; cssas pessoas devem exercer o livre dircito de escolha sem qualquer intervenção de clementos de força, fraude, mentira, coação, astúcia ou outra forma de restrição posterior; devem ter conhecimento suficiente do assunto em estudo para tomarem uma decisão. Essc último aspecto exige que sejam explicados às pessoas a naturcza, a duração e o propósito do experimento; os métodos segundo os quais șcrá conduzido; as inconveniências e os riscos esperados; os cfeitos sobre a saúde ou sobre a pessoa do participantc, que cventualmente possam ocorrer, devido à sua participação no experimento. $O$ dever $\mathrm{c}$ a responsabilidade de garantir a qualidade do consentimento repousam sobre o pesquisador que inicia ou dirige um cxperimento ou se comprometc nele. São deveres c responsabilidades pessoais que não podem ser delegados a outrem impuncmentc. (...) 4 . O experimento: deve ser conduzido de mancira a cvitar todo sofrimento c danos desnecessários, quer fisicos, quer materiais." (Cf. Santos, Maria Celestc Cordeiro Leitc. O cquilibrio de um pêndulo: bioética e a lei: implicaçõcs médico-lcgais. São Paulo: Íconc Editora, 1998, pp. 271-272).

72. A Convenção da Biodiversidade, art. $15, \S 5^{\circ}$, discorrc sobre consentimento informado.

73. Grecly, Henry T. The Control of Genetic Rescarch: Involving the "Groups Between". Houston Law Review, 33(5):1407, 1997.

74. Idem, ibidem, p. 1407, nota de rodapć n. 62.

75. Declaração de Helsinque (Associação Mćdica Mundial - 1964/1989): “3. [...] A responsabilidade sobre o ser humano deve recair sempre sobrc a pessoa com qualificação médica c nunca sobrc o indivíduo submctido a pesquisa mesmo que cssc individuo tenha dado seu consentimento. (...) 5. [...] Os interesses do individuo devem prevalecer sobrc os interesses da ciência c da sociedadc. (...) 9. Em qualquer pesquisa com scres humanos, cada participante $\mathrm{cm}$ potencial deve ser adequadamente informado sobre as finalidades, os métodos, os bencficios esperados, os possiveis riscos c sobre o desconforto que a pesquisa possa trazcr. O participante $\mathrm{cm}$ potencial deve ser informado de que tem plena liberdade para se abster de participação na pesquisa c de que ć livre para suspender o consentimento sobre sua participação a qualquer momento. O médico deve obter cntão o consentimento informado, dado de forma livre e preferentementc por cscrito. 10. Na obtenção de consentimento informado para projeto de pesquisa o médico deve ser particularmente cuidadoso com o indivíduo que, de alguma forma, dependa dele ou possa ter concordado sob pressão. Ncsse caso o consentimento esclarccido deve scr obtido pelo médico que não csteja cnvolvido na pesquisa c que seja completamente independente nesse relacionamento oficial. 11. No caso de incompetência legal, o consentimento esclarecido deve ser dado pelo responsável, estabelecido segundo a legislação do pais. Se a capacidade fisica e mental tornar impossivel obter consentimento informado ou sc o participantc for menor de idade, a permissão dada por um parente responsável substitui a do participante de acordo com a lcgislação de cada país." (Cf. Santos, Maria Ccleste Cordeiro Leitc. O cquilíbrio de um pêndulo: bioćtica c a leci: implicações médico-legais. São Paulo: Ícone Editora, 1998, pp. 272-275).

76. Brasil, Consclho Federal de Medicina. Código de Ética Médica (Resolução C.F.M. n. 1.154, de 13.04.84), Capitulo XII (Pesquisa Médica): "É vedado ao médico: Art. 122 - Participar de qualquer tipo 
Além de obter a permissão do governo, ${ }^{78}$ os pesquisadores deveriam obter o consentimento informado tanto da família ou do grupo étnico quanto do indivíduo que forem objeto de pesquisa genética. ${ }^{79} \mathrm{~A}$ informação sobre os genes de um membro de uma família proporciona necessariamente alguma informação sobre os genes dos. outros membros dessa família. ${ }^{80}$ Os pesquisadores estrangeiros deveriam, antes de coletar amostras de $\mathrm{ADN}$, solicitar autorização do governo. ${ }^{81}$ O estereótipo da coleta de amostras "bleed and run" ${ }^{\text {" } 2}$ deve ser repudiado. ${ }^{83}$ A utilização de recurso genético humano coletado sem a obtenção do consentimento informado deveria ser proibida legalmente.

Ao buscar o consentimento informado, o pesquisador deve informar tanto ao grupo quanto ao indivíduo o objetivo e a natureza da pesquisa, os riscos da participação na pesquisa e os benefícios que se esperam alcançar com sua participação. ${ }^{84}$

de experiência no ser humano com fins bélicos, políticos, raciais ou cugênicos. Art. 123 Rcalizar pesquisa $\mathrm{cm}$ ser humano, sem que este tenha dado consentimento por cscrito, após devidamente csclarccido sobre a natureza c a conseqüência da pesquisa. Parágrafo único: Caso o paciente não tenha condiçõcs de dar scu livre consentimento, a pesquisa somente será realizada, em scu próprio benefício, após expressa autorização legal de scu responsável. (...) Art. 125 Promover pesquisa médica na comunidade $5 \mathrm{~cm}$ o conhecimento dessa coletividade c sem que o objetivo seja a proteção da saúde pública, respeitadas as características locais."

77. -. Proposed Model Ethical Protocol for Collecting DNA Samples. Houston Law Review. 33(5):1.442, 1997.

78. Council for International Organizations of Medical Sciences (CIOMS), cm colaboração com a Organização Mundial de Saúde (OMS), Genebra - 1993. Diretrizes Éticas Internacionais para Pesquisas Envolvendo Seres Humanos. "Diretriz 15: Obrigações dos paíscs patrocinador c anfitrião [...] - Após a aprovação ética c científica no pais da agência patrocinadora, as autoridades competcntes do pais anfitrião, incluindo o comitê nacional ou local de revisão ética, ou scu cquivalente deve satisfazcr suas próprias exigências com relação à pesquisa proposta." (Cf. Santos, Maria Celeste Cordciro Lcitc. O equilibrio de um pêndulo: bioética c a lci: implicações médico-legais. São Paulo: Íconc Editora, 1998, pp. 275-280).

79. Proposed Model Ethical Protocol for Collecting DNA Samples. Houston Law Review, 33(5): 1437, 1997.

80. Greely, Henry T. The Control of Genctic Rescarch: Involving the "Groups Betwcen". Houston Law Review, 33(5):1.426, 1997.

81. Proposed Model Ethical Protocol for Collecting DNA Samples. Houston Law Review, 33(5):1.441-1.442, 1997.

82. A cxpressão "bleed and run" designa o hábito de alguns pesquisadorcs de abandonar a comunidadc, logo após colctar amostras sangüincas. Muitas vezes, pesquisadores colctam amostras sangüincas sob o pretexto de fazerem exames de malária, ancmia ou verminose.

83. -. Proposed Model Ethical Protocol for Collecting DNA Samples. Houston Law Review, 33(5): 1.438 .

84. Ibidem, p. 1.448. 
Embora não se possa transmitir uma explicação aprofundada de genética humana e biologia molecular, os pesquisadores deveriam explicar, numa linguagem compreensivel, o objeto da pesquisa.$^{85} \mathrm{~A}$ explicação fundamental deveria centrar-se na idéia de que os seres humanos herdam características de seus antepassados. ${ }^{86}$

Os pesquisadores têm a obrigação de fornecer à população informações honestas e significativas. ${ }^{87}$ Ao buscar o consentimento informado, os pesquisadores não deveriam assegurar que a pesquisa genética, por exemplo, curará a doença hereditária que afeta, por exemplo, toda uma família. ${ }^{88}$ Também se deveria informar que as amostras podem ser utilizadas para uma variedade de projetos diferentes no futuro, incluindo projetos cujas conseqüências, atualmente. não podem ser previstas. ${ }^{89}$ As amostras podem ser utilizadas com variados objetivos, sendo que o mais importante é a análise do funcionamento das doenças genéticas. ${ }^{90}$

Mesmo se as amostras de $\mathrm{ADN}$ não forem consideradas propriedade dos indivíduos que as forneceram, deve-se exigir a obtenção do consentimento informado para sua coleta. ${ }^{91} \mathrm{O}$ consentimento informado, em algumas culturas, deveria assumir uma forma escrita, sendo devidamente assinado. ${ }^{92}$

Caso um indivíduo ou um grupo concordar em participar de uma pesquisa genética sob pagamento, sérias dúvidas podem surgir sobre a licitude deste procedimento. Se o pagamento for muito significativo, talvez se suspeite de coerção. ${ }^{93}$ Tanto o indivíduo quanto o grupo não poderiam dizer não. A cada indivíduo ou grupo

85. Ib., p. 1.437.

86. Ib., pp. 1.448-1.449.

87. Ib., p. 1.450.

88. Ib., p. 1.453.

89. Ib., p. 1.448.

90. Ib., p. 1.448.

91. Greely, Henry T. The Ethics of the Human Genome Diversity Project: The North American Regional Committec's Proposed Model Ethical Protocol. In: Human DNA: Law and Policy; International and Comparative Perspectives. The Hague/London/Boston, Kluwcr Law International, p. 249.

92. Proposed Model Ethical Protocol for Collecting DNA Samples. Houston Law Review. 33(5):1.451., 1997: "The United States, for example, generally requires signed consent forms from all individuals participating in federally funded research who are subject to a risky procedure."

93. Ibidem, pp. 1.454-1.455. 
deveria ser dado o direito de escolher se quer ou não-participar de uma pesquisa genética. ${ }^{94}$ Se o conceito "informação genética" for concebido de uma maneira excessivamente abrangente, ele poderia incluir toda espécie de informação médica. ${ }^{95}$

A obtenção de consentimento informado para uma pesquisa, cujas amostras de ADN já foram coletadas, pode constituir um procedimento dispendioso. ${ }^{*}$ Nem todos os que forneceram as amostras poderão ser facilmente localizados. Como, para patentear seqüências de $\mathrm{ADN}$, não se exige que se comprove a obtenção do consentimento informado para a coleta de amostras de ADN, muitos pesquisadores negligenciam a importância de se obter o já referido consentimento informado dos indivíduos ou grupos objeto de pesquisas genéticas. Para amostras não-identificadas, o consentimento informado não seria exigido. ${ }^{97}$ A não-identificação de amostras pode constituir, no entanto, um mecanismo sorrateiro para que os lucros ganhos com a exploração comercial do $\mathrm{ADN}$ coletado não sejam eqüitativamente distribuídos entre o pesquisador e a população pesquisada.

Os indivíduos ou grupos precisam ser avisados que o material coletado poderá dar ensejo a alguma modalidade de exploração comercial. A possibilidade de ganhos com esta modalidade de exploração comercial do material coletado pode induzir indivíduos ou grupos a participar da pesquisa. Pesquisas com material genético humano podem levar à fabricação de produtos que valham milhões ou mesmo bilhões de dólares. ${ }^{98}$ Cerca de $10 \%$ dos lucros poderiam ser distribuídos entre os indivíduos ou grupos que participaram da pesquisa, com amostras de ADN. Vastas somas de recursos costumam ser investidas, por exemplo, na produção de medicamentos derivados de genes. Todavia, uma distribuição de $10 \%$ dos lucros não parece constituir, necessariamente, uma alternativa justa, caso os ganhos advierem especificamente do patenteamento de uma seqüência de $\mathrm{ADN}$, enquanto tal.

94. Grecly, Henry T. The Ethics of the Human Genome Divcrsity Project: The North Amcrican Regional Committec's Proposed Model Ethical Protocol. In: Human DNA: Law and Policy; International and Comparative Perspectives. The Haguc/London/Boston, Kluwer Law International, p. 245.

95. Idem, Legal, Ethical, and Social Issucs in Human Genome Research. Annu. Rev. Anthropol., (27):491, 1998.

96. Idl., Breaking the Stalematc: A Prospective Regulatory Framework for Unforescen Rescarch Uses of Human Tissuc Samples and Health Information. Wake Forest Law Review, 34(3):740, Fall 1999.

97. Id., ibidem, p. 749.

98. Idl., ib., p. 757. 
O precedente Norman Bloodsaw v. Lawrence Berkeley Lab. ${ }^{99}$ prevê que a utilização de amostras de sangue para a obtenção de informações médicas de natureza intima, como, por exemplo, gravidez, infecção sifilítica, sem consentimento específico para tal, pode constituir uma infração à lei..$^{10}$

\section{Consentimento individual}

Um membro de uma família ou de um grupo étnico pode recusar-se a participar de uma pesquisa genética, mas os resultados da pesquisa revelarão algo sobre ele, à família, ao grupo étnico ou mesmo ao mundo exterior. Na melhor das hipóteses, será revelado que ele, ou seus descendentes, terão uma probabilidade maior de desenvolver uma doença genética específica. Sua decisão de não-participar da pesquisa genética terá pouco significado. A pesquisa genética fornecerá informação sobre a família ou o grupo étnico, bem como sobre os indivíduos que fazem parte dessa família ou desse grupo étnico. Com o consentimento informado de apenas alguns indivíduos, obtêm-se informações sobre todos os indivíduos que fazem parte de uma família ou de um grupo étnico. ${ }^{101}$

A autonomia individual pode, portanto, revelar-se artificial. A pesquisa será efetuada sobre um grupo, bem como sobre os indivíduos que fazem parte desse grupo. O grupo - seja uma família, um grupo de famílias ou um grupo étnico - constitui efetivamente o objeto da pesquisa. ${ }^{102}$

A pesquisa sobre um grupo proporciona efetivamente informação sobre todos os membros do grupo. Os membros do grupo podem ter sua reputação prejudicada. Eles podem encontrar dificuldades em encontrar trabalho, bem como em associar-se a uma seguradora médica, independentemente de terem ou não- conferido seu consentimento para a realização da pesquisa. Se forem estabelecidos vínculos entre características genéticas e orientações comportamentais, os membros do grupo podem terminar sendo considerados geneticamente violentos, emocionalmente instáveis ou imbecilizados. ${ }^{103}$

99. Norman Bloodsaw v. Lawrence Berkeley Lab., 135 F. 3d 1260 (9th Cir. 1998).

100. Grecly, Henry T. Legal, Ethical, and Social Issucs in Human Genome Rescarch. Annu. Rev. Anthropol., (27):491, 1998.

101. Ill., The Control of Genctic Research: Involving the "Groups Between". Houston Law Review. 33(5):1.412, 1997.

102. Id., ibidem, p. 1.412 .

103. Id., ib., p. 1.412. 
Como a pesquisa genética proporciona informação sobre todos os membros da família ou do grupo étnico, eles podem sofrer conseqüências em sua reputação. Alguns podem ter dificuldades em casar-se, associar-se a um plano de saúde, encontrar trabalho, tenham ou-não manifestado seu consentimento em benefício da pesquisa genética.

Os resultados da pesquisa genética, todavia, podem trazer benefícios. Dependendo da atitude a ser tomada pelo indivíduo, tratamentos médicos poderão ser iniciados, para que se combata o surgimento dos sintomas da doença genética diagnosticada, quando isto for possível. ${ }^{104}$

\section{6) Consentimento coletivo}

Ao buscar-se o consentimento informado, deve-se pedir, portanto, ao grupo que decida se quer permitir a utilização comercial, bem como a obtenção, e em que termos, de patentès derivadas de seu material genético. $O$ grupo pode decidir que deseja apenas uma dessas modalidades, ou nenhuma delas. O grupo também pode decidir que permitirá a utilização comercial, bem como o patenteamento, somente em função de acordos expressos a serem negociados subseqüentemente. ${ }^{105}$

Os pais têm poderes jurídicos sobre seus filhos. Todavia, unidades familiares maiores, que incluem vários membros adultos, geralmente não costumam dispor de uma unidade central de poder. Cada membro adulto decide, por si próprio, se deseja ou não-participar de uma pesquisa biomédica. Os membros de uma família extensa, que não seja mononuclear, não dispõem de poderes jurídicos uns sobre os outros. Alguns membros podem controlar ou influenciar, devido ao seu prestígio, as decisões do grupo em participar ou-não de uma pesquisa biomédica que terá implicações para toda a família. ${ }^{106}$

Distinguir qual é o centro de autoridade numa família extensa pode ser praticamente impossível. A distribuição dos benefícios da exploração comercial, bem como do patenteamento, pode tornar-se, portanto, uma tarefa extremamente complexa. ${ }^{107}$ Também membros já falecidos de uma família constituem objeto de uma

104. Id., ib., p. 1.413 .

105. Ib., ib., p. 1.419 .

106. Id., ib., p. 1.427 .

107. Id., ib., p. 1.429 . 
pesquisa genética, à medida que os pesquisadores indagarão se eles sofriam ou-não de uma doença transmissível geneticamente.

Além do consentimento individual, também se deve buscar o consentimento coletivo da população objeto da pesquisa genética, a despeito das dificuldades operacionais que possam surgir. Muitas vezes, a coleta de ADN será efetuada em populações marginalizadas, tanto política quanto economicamente, em seu próprio país. Elas podem ter sido submetidas a discriminação, opressão ou até mesmo a genocídio. ${ }^{108}$ Sendo assim, não se deveriam coletar amostras de ADN de um grupo de indivíduos, sem que o próprio grupo se tenha manifestado favoravelmente à realização da pesquisa genética. ${ }^{109}$ Antes de iniciar a coleta de $\mathrm{ADN}$, os pesquisadores deveriam obter o consentimento informado das autoridades que representam a população objeto da pesquisa. ${ }^{110}$ Conselhos de anciães, lideranças religiosas constituem geralmente autoridades representativas. "' O consentimento coletivo só pode ser conferido, depois que os pesquisadores tiverem explicado aprofundadamente o objeto de sua pesquisa. ${ }^{1 / 2}$

Se um grupo indígena, como os Karitiana, decidir que não quer ser objeto de uma pesquisa genética, nenhum indivíduo pertencente a este grupo deveria ser pesquisado; ${ }^{1 / 3}$ não se deveria colher nenhuma amostra individual de ADN. Como esta espécie de pesquisa genética tem uma base grupal, o consentimento informado coletivo é essencial." 14 Algumas vezes, não será facilmente identificada uma autoridade habilmente constituída capaz de fornecer o consentimento informado em nome seja de uma família, seja de um grupo étnico. ${ }^{115}$

Caso uma pesquisa genética tiver como objeto a população de uma cidade,

108. -. Proposed Model Ethical Protocol for Collecting DNA Samples. Houston Law Review, 33(5):1.443, 1997.

109. Ibidem, p. 1.443.

110. Ib., pp. I.443-1.444.

111. Ib., p. 1.446.

112. Ib., p. 1.444 .

113. Grecly, Henry T. The Control of Genetic Research: Involving the "Groups Between". Houston Law Review, 33(5):1416, 1997.

114. -. Proposed Model Ethical Protocol for Collecting DNA Samples. Houston Law Review, 33(5):1.444, 1997.

115. Grecly, Henry T. The Control of Genetic Rescarch: Involving the "Groups Between". Houston Law Review, 33(5):1417, 1997. 
de uma aldeia ou de um grupamento religioso, dever-se-ia buscar o consentimento coletivo das respectivas autoridades. Quando tais autoridades não dispuserem de legitimidade, perante a opinião pública, para conceder esta espécie de consentimento, dever-se-ia buscar o consenso da população em beneficio da pesquisa genética. ${ }^{116} \mathrm{Tal}$ consenso poderia ser atingido mediante campanhas de esclarecimento. Mesmo se tendo obtido o consentimento informado das autoridades que representam a população objeto da pesquisa, também se deveria buscar autorização para coleta de $\mathrm{ADN}$ junto à própria população. ${ }^{117}$

Cada população objeto de uma pesquisa genética deveria ter o direito de manifestar-se contra ou a favor do patenteamento de invenções derivadas de seu material genético. Caso se manifeste a favor do patenteamento, os lucros obtidos com o respectivo patenteamento de invenções derivadas de seu material genético deveriam ser distribuídos eqüitativamente entre ela e o pesquisador. ${ }^{118}$ Também se deveriam distribuir eqüitativamente os lucros obtidos com a exploração comercial de tal material genético, que pode ser, por exemplo, incluído numa base de dados genética e comercializado com terceiros, até mesmo online.

O consentimento coletivo deveria ser procurado preferencialmente junto a populações bem definidas culturalmente. ${ }^{119}$ A consulta com antropólogos e outros especialistas geralmente será essencial. ${ }^{20}$ Os pesquisadores devem aprender o máximo possível sobre a população que será objeto da coleta de amostras de ADN. ${ }^{121}$ Eles precisam descobrir quais grupos da população têm legitimidade para autorizar a realização da pesquisa. ${ }^{122}$

Grupos vulneráveis devem ser especialmente protegidos, como menores

116. -. Proposed Model Ethical Protocol for Collecting DNA Samples. Houston Law Review, 33(5):1.444, 1997.

117. Ibidem, p. 1.445 .

118. Grecly, Henry T. Informed Consent, Stored Tissuc Samples, and the Human Genome Diversity Project: Protecting the Rights of Rescarch Participants. In: Stored Tissue Samples; Ethical, Legal and Public Policy Implications. University of Iowa Press, p. 95.

119. Idem, ibidem, p. 95.

120. -. Proposed Model Ethical Protocol for Collecting DNA Samples. Houston Law Review, 33(5):1.436, 1997.

121. Ibidem, p. 1.438.

122. Ib., p. 1.439 . 
de idade e deficientes mentais. Não se deveriam realizar pesquisas genéticas com tais grupos, devido às sérias questões éticas envolvidas nesta espécie de pesquisa. ${ }^{123}$

\section{Conclusão:}

A legislação brasileira exige que os pesquisadores submetam propostas para estudo de seres humanos a comitês de especialistas, que precisam analisar se tais propostas se coadunam com a legislação de proteção aos direitos humanos. Declarações internacionais também protegem o ser humano submetido a pesquisas biomédicas. ${ }^{124}$ Tanto a legislação brasileira quanto declarações internacionais exigem que o indivíduo ou o grupo sujeito a pesquisa biomédica seja plenamente informado sobre a natureza, o objetivo e os riscos da pesquisa, bem como que concordem formalmente em participar da mesma. ${ }^{125}$ Exige-se, fundamentalmente, que os riscos aos quais serão submetidos os indivíduos sejam justificados em função dos beneficios potenciais da pesquisa, que o consentimento informado seja obtido e que grupos vulneráveis ${ }^{126}$ sejam especialmente protegidos. ${ }^{127}$

123. Ib., p. 1.443.

124. "A Itália, cm scu projeto de Novo Código Pcnal, sob o título de: 'Os delitos contra o mcio ambiente', prevê um tipo preventivo de cxercicio abusivo de atividades de investigação ou cxperimentação, scm autorização, ou violando-as, pcla inobscrvância de normas prescritas c/ou subtração aos controles prescritos." (Cf. Santos, Maria Celestc Cordciro Leitc. O cquilibrio de um pêndulo: bioćtica c a lci: implicaçõcs médico-legais. São Paulo: İconc Editora, 1998, p. 172)

125. Brasil, Sociedade Brasilcira de Medicina Tropical c Associação Brasilcira de Antropologia, 1986. Código de Dircitos de Saúde das Comunidades, "Art. $1^{\circ}$ : É cssencial para a comunidade scr organizada pois assim poderá participar, atravćs de suas lideranças c organizaçõcs, ao longo das investigaçõcs; Art. $2^{\circ}$ : A comunidade tem o dircito de ser plenamente informada sobre a naturcza, objetivos, vantagens $\mathrm{c}$ cventuais riscos da pesquisa a scr realizada; c Art. $3^{\circ}$ : Ninguém poderá ser submetido a investigação scm que tenha sido previamentc informado c concordado." (Cf. Santos, Maria Celeste Cordciro Leitc. O cquilibrio de um pêndulo: bioćtica c a Ici: implicações médico-legais. São Paulo: İ́conc Editora, 1998, pp. 280-281).

126. İ́dios cstão sendo o alvo central das empresas especializadas, pcla característica de maior homogencidade genćtica, $\mathrm{cm}$ reduzido grupo humano. O objetivo é o mercado de genes identificados com potencial de patente para exploração industrial. É uma área de negócios milionários. No ano passado, nos Estados Unidos, os dircitos sobre um único gene útil para pesquisas sobre obesidade teriam sido vendidos por R \$ 70 milhões (Ćf. Casado, Josć. Amazônia, o paraíso da biopirataria. In: O Estado de S. Paulo. Sç̧ão Ciĉncia, 15/11/96, p. A-17, apud Santos, Maria Celcstc Cordciro Lcitc. O cquilibrio de um pêndulo: bioćtica c a lci: implicaçõcs médico-legais. São Paulo: Íconc Editora, 1998, pp. 172-173).

127. Council for International Organizations of Mcdical Sciences (CIOMS), $\mathrm{cm}$ colaboração com a Organização Mundial de Saúde (OMS), Gencbra, 1993. Dirctrizes ćticas internacionais para pesquisas cnvolvendo scres humanos. "Dirctriz 4: Induçăo a participação. Os indivíduos poderão ser pagos pela inconveniĉncia c pelo tempo gasto, $\mathrm{c} \mathrm{devem} \mathrm{ser} \mathrm{recmbolsados} \mathrm{das} \mathrm{despesas} \mathrm{decorrentes} \mathrm{da} \mathrm{sua} \mathrm{participaçào}$ na pesquisa; cles podem recebcr, igualmente, scrviços médicos gratuitos. Entrctanto, os pagamentos não 
A Constituição Federal, art. 225, caput, determina: "Todos têm direito ao meio ambiente ecologicamente equilibrado, bem de uso comum do povo e essencial à sadia qualidade de vida, impondo-se ao Poder Público e à coletividade o dever de defendê-lo e preservá-lo para as presentes e futuras gerações" Para assegurar a efetividade desse direito, incumbe ao Poder Público "preservar a diversidade e a integridade do patrimônio genético do país e fiscalizar as entidades dedicadas à pesquisa e manipulação de material genético" (art. 225, § $1^{\circ}$ II).

O Projeto de Lei de Acesso à Biodiversidade (PL n. 306/95), art. $8^{\circ}$, determina, por sua vez, que o mesmo não se aplica: "I - aos materiais genéticos e quaisquer componentes ou substâncias dos seres humanos, ficando toda coleta ou uso desses recursos, componentes ou substâncias dependente de aprovação do Poder Executivo, após o consentimento prévio fundamentado do indivíduo, até que entre em vigor lei específica sobre esta matéria."

A Convenção de Biodiversidade não dá sinais de que regulou a exploração do ADN humano. ${ }^{128}$ A Medida Provisória n. 2.126-11, de 26 de abril de 2001, determina, expressamente, que: "Esta Medida Provisória não se aplica ao patrimônio genético humano" (art. $\left.3^{\circ}\right)$.

Quando se patenteia um recurso genético humano, por outro lado, não se analisa sua origem, tampouco se exige a obtenção de qualquer espécie de consentimento informado.

A Diretiva Européia de Biotecnologia, que até julho de 2000 deveria ter sido transplantada para o direito interno dos respectivos países-membros, dispunha inicialmente de uma emenda, a Emenda n. 76, cujo objetivo era limitar a biopirataria, a qual terminou sendo completamente removida pela Comissão. Quando se solicitasse uma patente sobre material vegetal ou animal, o pedido deveria comprovar que se havia obedecido a legislação do país de origem no que diz respeito ao acesso e exportação desse material. Quando o pedido versasse sobre material humano, o pedido deveria comprovar o consentimento informado da pessoa, cujo material genético se

\footnotetext{
devem ser tão grandes ou os scrviços médicos tão abrangentes a ponto de induzircm os possíveis sujeitos a conscntirem participar na pesquisa contra o scu melhor julgamento ('indução cxcessiva'). Todos os pagamentos, recmbolsos c serviços médicos propiciados aos sujeitos da pesquisa devem ser aprovados por um Comitê de Ética." (Cf. Santos, Maria Cclcstc Cordciro Lcitc. O cquilibrio de um pêndulo: bioćtica c a lci: implicações médico-legais. São Paulo: Íconc Editora, 1998, p. 276).
}

128. Grecly, Henry T. The Control of Genctic Research: Involving the "Groups Betwecn". Houston Law Review, 33(5):1.404, 1997. 
pretendesse patentear. ${ }^{129} \mathrm{Sem}$ tal emenda, recursos genéticos humanos ${ }^{130}$ podem ser patenteados na União Européia sem a comprovação de obtenção de consentimento informado. ${ }^{131}$

São Paulo, setembro de 2001.

129. .. EU hard at work on a bio-piracy patent directivc. http://platon.ce,duth.gr/data/maillist-archives/ deukalion/1998ao/msg00023.html (17/02/00).

130. Pesquisadores teriam recebido um catálogo da Coriell Cell Repositores, banco de cćlulas, com sede em Nova Jersey, anunciando a venda de células de 17 (dezessete) povos indígenas dos cinco continentes. Entre as amostras de material genético (ADN) da Amćrica do Sul à venda, duas scriam de tribos Karitianas c Suruis, de Rondônia (Cf. Casado, Josć. Amazônia, o paraiso da biopirataria. In: O Estado dc S. Paulo. Seção Ciência, 15/11/96, p. A-17. apud Santos, Maria Cclcstc Cordeiro Lcitc. O equilíbrio de um pêndulo: bioćtica c a lei: implicaçõcs médico-legais. São Paulo: Íconc Editora, 1998, pp. 172-173).

131. -. EU hard at work on a bio-piracy patent directivc. http://platon.ce.duth.gr/data/maillist-archives/ deukalion/1998ao/msg00023. html (17/02/00). 